Fourth International Conference on Sustainable Construction Materials and Technologies

http://www.claisse.info/Proceedings.htm

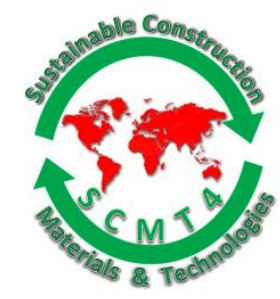

SCMT4

Las Vegas, USA, August 7-11, 2016

\title{
Bacterial Crack Sealing and Surface Finish Application to Concrete
}

\author{
Alan Richardson ${ }^{1 \mathrm{a}}$, Kathryn Coventry ${ }^{1 \mathrm{~b}}$, and Jack Pasley ${ }^{1 \mathrm{c}}$ \\ ${ }^{I}$ Northumbria University, Newcastle upon Tyne, NE1 8SA, UK. \\ ${ }^{1 a}$ Email: <alan.richardson@northumbria.ac.uk>.
}

\begin{abstract}
This paper investigates the sealing and healing properties micro-induced calcite precipitation with regard to improving concrete finish, sealing cracks and cementing loose surface particles together. Sporosarcina pasteurii has been used to effectively precipitate calcium carbonate in order to seal porous media. The bacteria are fed a nutrient broth mix to create conditions where MICP can be effectively used. The tests carried out, assessed the effect of MICP on a sample of twenty-four concrete cubes and to what extent the surface has been consolidated. The use of an Alicona $4 \mathrm{G}$ infinite focus scanner provided comprehensive analysis of how the sample cubes' topography had been altered following the treatment. In addition, three fibre reinforced concrete beams were micro-cracked to evaluate $\mathrm{t} S$. pasteurii's ability to seal cracks that are common in concrete structures globally. Calcite deposits were observed to be effective at sealing cracks and consolidating the surface finish of the concrete. The treatment is an organic remedial method that has industrial applications.
\end{abstract}

\section{INTRODUCTION}

Concrete is an inherent part of our built environment, but it is not without its problems. As with any building material, deterioration is an expected occurrence with regards to the service life of structures. Both stone and concrete are susceptible to weathering; a breakdown of the mineral matrix leads to increased porosity of the surface and with it brings numerous issues (De Muynck, De Belie, et al., 2010). The lack of a costeffective, eco-friendly repair method is a cause for concern: 'In the United States of America, for instance, the annual direct costs for maintenance and repair of concrete highway bridges due to corrosion of the reinforcement sum up to 4 billion dollars' (Sierra-Beltran et al., 2014) Steel corrosion is one consequence of moisture penetration resulting from a variety of factors.

With more extreme weather now common place, concrete structures within our society are subject to forces which in turn lead to micro scale propagation damage. The porosity of concrete means that if micro-cracks propagate, they provide an easy path for the transportation of liquids and gasses that potentially contain harmful substances which may damage the structure (Van Tittelboom et al., 2010). Micro cracks are commonplace in concrete structures, Eurocode 2 permits cracks widths up to $0.3 \mathrm{~mm}$. Micro cracks need to be attended to in order to stop them propagating and leading to costly repairs. Cracks under $0.05 \mathrm{~mm}$ are not deemed problematic as concrete can repair itself through swelling of the cement paste, hydration of the remaining un-hydrated cement, precipitation of calcium carbonate $\left(\mathrm{CaCO}_{3}\right)$ crystals, and crack filling by impurities in water or by debris from the crack surface (Stuckrath et al., 2014). Additionally, the life cycle 
costs of buildings are under more scrutiny than ever; buildings need to require less maintenance and have longer life spans to become more eco-friendly (Srinivasan et al., 2014) and in this vein MCIP provides and alternative repair, sealing and reinstatement method.

\section{Causes of Deterioration and transport mechanisms}

The durability of concrete is fundamentally dependent on the ease, or difficulty it can repel fluids in either liquid or gas form from permeating its surface. Concrete is a porous material and the number, type and size of its pores influence its durability (Basheer \& Barbhuiya, 2010). Deterioration of a concrete surface happens in three, chemico-physical stages (Lambert, 2002).

1. Initiation

2. Propagation

3. Deterioration.

\section{Traditional Remedial Methods}

The majority of traditional remedial methods available are largely based on environmentally unfriendly materials such as epoxy systems, acrylic resins or silicone-based polymers (Sierra-Beltran et al., 2014). Traditional inorganic coatings consist of calcium-silicate compounds, which exhibit a composition similar to cement (De Muynck et al., 2008).

The repair of concrete structures falls into three basic categories:

- Structural

- Semi-Structural

- Cosmetic

In the context of this investigation, it is only anticipated to provide solutions to the cosmetic element of remedial works, which is described by The Concrete Society, (2009) as when holes do not surpass the reinforcement with the repair materials used based on lightweight solutions; either a cementitious or polymer binder. These solutions are unlikely to possess the same qualities as the original concrete in terms of elastic modulus, creep and shrinkage (The Concrete Society, 2009).

\section{Materials and bacteria}

The mix designs used in this paper are displayed in Table 1 . The change in water cement ratio provided varying porosity and surface finish to provide different surface conditions. A steel float finish was provided to the test surface and this was lightly trowelled to provide a textured surface.

Table 1. Mix design

\begin{tabular}{|l|l|l|}
\hline $0.8 \mathrm{WCR}$ & Constituent & $0.4 \mathrm{WCR}$ \\
\hline $170 \mathrm{~kg} / \mathrm{m}^{3}$ & Cem $152.2(\mathrm{R})$ & $337 \mathrm{~kg} / \mathrm{m}^{3}$ \\
\hline $652 \mathrm{~kg} / \mathrm{m}^{3}$ & Sand $<4 \mathrm{~mm}$ & $482 \mathrm{~kg} / \mathrm{m}^{3}$ \\
\hline $1522 \mathrm{~kg} / \mathrm{m}^{3}$ & Gravel $<20 \mathrm{~mm}$ & $1526 \mathrm{~kg} / \mathrm{m}^{3}$ \\
\hline $136 \mathrm{~L} / \mathrm{m}^{3}$ & Water & $134.8 \mathrm{~L} / \mathrm{m}^{3}$ \\
\hline
\end{tabular}

When the bacterial broth is applied to the cubes and beams, it will need to pool on the concrete surface and not run off, a silicone bead was applied around the edge of the cubes to ensure the mixture stays within the desired surface area. Similarly, a retaining bead of silicone will be applied around the induced cracks on the beams to contain the mixture and on the sides to contain the bacterial broth.

\section{BACTERIA}

Bacteria are abundant, incredibly diverse and conduct precipitation of mineral carbonates across a spectrum of natural environments (Siddique and Chahal, 2011). The majority of bacteria are either spheres and known as cocci or rod shaped and referred to as bacilli (Siddique and Chahal, 2011). 
Bacteria Calcite Precipitation. In nature, it is common for microbial mineral plugging to occur in porous media (Stocks-fischer et al., 1999). Bio-calcification or microbiologically induced calcite precipitation (MICP) is a phenomenon concerning the urease enzyme (Sarda et al., 2009). Microbial $\mathrm{CaCO}_{3}$ has wide scope, as it has a varied range of environmentally friendly applications. It can consolidate damaged materials, especially ones bearing cracks (Wang et al., 2014). MCIP is a natural phenomenon which is associated with a range of bacteria species given the right conditions, in particular, an alkaline environment rich in $\mathrm{Ca}_{2}{ }^{+}$ions (Achal and Pan, 2011). The calcite deposition is able to consolidate media and potentially reduce moisture ingress.

Ureolytic Activity. Bacteria that hydrolyse with urea are the most investigated with regard to calcite production. One molecule of urea is hydrolysed intracellularly to 1 molecule of ammonia and 1 molecule of carbonate, which then spontaneously hydrolyses to form an additional molecule of ammonia and carbonic acid. In water, the products then form bicarbonate, 2 molecules of ammonium, and 2 molecules of hydroxide ions. It is mentioned by Zamarreño et al. (2009) that a correct temperature of between $22^{\circ} \mathrm{C}$ and $32^{\circ} \mathrm{C}$ is required to catalyse the process.

Microbiologically Induced Precipitation. A more complex pathway to derive calcite precipitation is through microbiologically induced precipitation (Siddique and Chahal, 2011). It relies on bacteria such as Sporosarcina pasteurii, urease and a high $\mathrm{pH}$ level. The enzyme catalyses the hydrolysis of urea to produce $\mathrm{CO}_{2}$ and ammonia, which, in turn, increases both the $\mathrm{pH}$ and carbonate concentration in the bacterial environment (Chahal et al., 2012).

Bioremediation. A bacterial cell surface can provide a nucleation site to non-specifically induce mineral deposition due to its variety of ions (Siddique and Chahal, 2011). Bacteria have the largest surface area to volume ratio of any life form (Fortin et al., 1996). Therefore they are able to harbour calcium carbonate formation as shown in Figure 1.
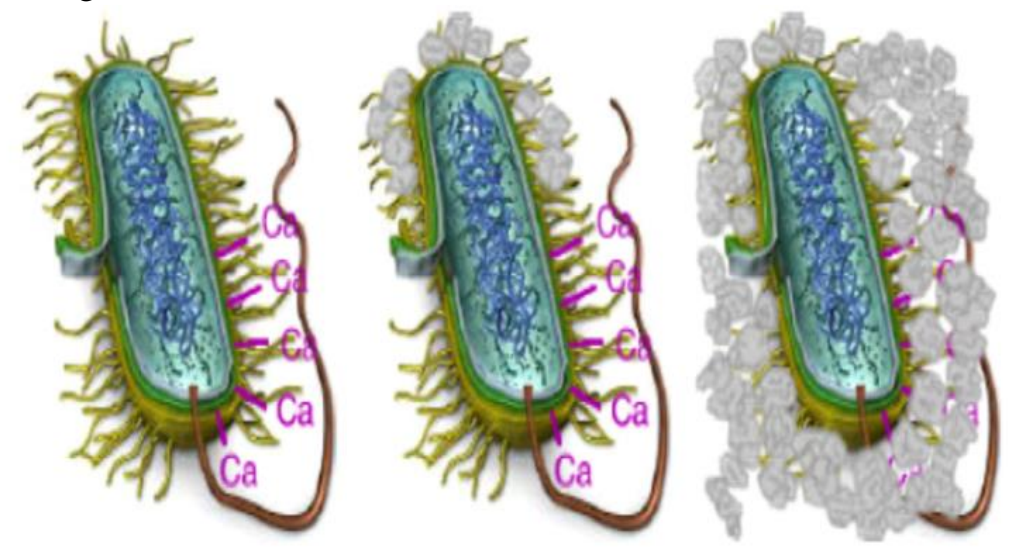

Figure 1. Simplified Ureolysis Calcite Precipitation (De Muynck, De Belie, et al., 2010)

\section{Calcite Precipitation in Concrete}

Numerous studies have being conducted to assess the effectiveness of calcite precipitation in concrete. As discussed, Stocks-fischer et al. (1999) outlined that such precipitation can plug porous media.

Sporosarcina pasteurii (Previously Bacillus pasteurii), is able to aid in the urease production which, in turn, hydrolyses urea to ammonia and $\mathrm{CO}_{2}$ (Bang et al., 2001). Such urease production from Sporosarcina pasteurii (S. pasteurii) was witnessed by (Sarda et al., 2009), stating among the other microbial cultures $S$. pasteurii NCIM 2477 was able to produce the most urease.

It is concluded by Siddique and Chahal (2011) that microbial mineral precipitation is a promising technique with regard to improvements in the compressive strength, permeability, lesser water absorption and reduced chloride ingression. 
Wiktor and Jonkers (2011) support this conclusion; their bio-chemical healing agent consisting of bacterial spores (Bacillus alkalinitrilicus, an alkali resistant soil bacterium) and calcium lactate was able to void cracks whilst being submersed in tap water for 100 days. The deposits were then tested using energy dispersive spectroscopy. The results verified the anticipated $\mathrm{CaCO}_{3}$ production as the deposits were a combination of calcium, oxygen and carbon atoms.

$S$. pasterurii is conveyed as consistently being able to produce urease, which is of paramount importance with regards to $\mathrm{CaCO}_{3}$ precipitation. It is apparent, Sporosarcina pasteurii appears to be the bacteria of choice throughout the various studies by Bang, Galinat, \& Ramakrishnan (2001) and Achal \& Pan (2011) and will subsequently be the bacteria to be used in this study.

\section{EXPERIMENTAL INVESTIGATION}

To assess any changes to surface finish, twenty-four, $100 \mathrm{~mm}$ concrete cubes were produced. The sample included two water cement ratios (WCR) and different surface finishes in equal numbers (six each). To quantify the calcite deposition, the comparable weights of the dry cubes pre and post treatment were recorded. The cubes were scanned to determine calcite deposition and change in surface roughness, waviness and pore volume.

Three fibre concrete beams were cast and once fully cured, they were cracked under a three point bending system, then a bead of silicone was applied around the cracked area to provide a reservoir to retain the liquid whilst the bacteria fed upon the food source, thus creating calcite as a repair agent.

The process outlined was repeated a total of three times, at 24 hour intervals and this layering effect gave the mixture time to be absorbed by the beams. Once the bacteria and the nutrient broth was mixed together, there was calcite formed almost immediately and this is a key finding in terms of an application process. This effect was noted in an earlier test. (Richardson et al 2014).

\section{Bacterial preparation and application}

The $S$. pasteurii cultures were suitably incubated in an orbital incubator at $37^{\circ} \mathrm{C}$ at a rate of $200 \mathrm{rpm}$. The cultures were then measured at $\mathrm{OD}_{600}$ to see if the cell density is within the desired range (Approx. 0.9-3). A higher OD will provide more nucleation sites for calcite formation.

Once the culture was prepared a $100 \mathrm{ml}$ aliquot containing the bacterial cultures was added to a $900 \mathrm{ml}$ Duran container of nutrient broth with $50 \mathrm{ml} \mathrm{CaCl}_{2}$ (calcium chloride) at a concentration of $1 \mathrm{~g} / \mathrm{ml}$. Immediately after mixing the solution, it was applied to the 3 beam sections and cubes. $15 \mathrm{ml}$ of solution per cube was applied followed by $1.5 \mathrm{ml}$ of urea to catalyse the reaction and help support the bacteria's hydrolysis, leading to a higher calcite yield.

\section{Scanning of Cubes}

In order to further gauge the impact of surface applied bacteria on the cubes, a sample is to be scanned using an Alicona measurement system (Figure 3.2). Four cubes, two from each WCR, with both sponge and trowel finishes will be scanned before and after the treatment. The Alicona system is capable of: Twodimensional surface roughness $\left(\mathrm{R}_{\mathrm{a}}, \mathrm{R}_{\mathrm{t}}\right)$, waviness, dimension measurement as well as the volume of surface pores to a resolution of $40 \mathrm{~nm}$. The measurement system is also capable of providing complete 3D information through measuring the coordinates $(\mathrm{X}, \mathrm{Y}, \mathrm{Z})$ of millions of points on the scanned samples and the data can be presented in true colour.

\section{RESULTS AND DISCUSSIONS}

The bacterial residue was examined at the surface (foreground) and at the intersection between the calcite and the concrete (background), using an Energy Dispersive Spectroscopy (EDS) image analysis technique and the chemical component parts are displayed in Table 3 and Figure 2. 
Table 3. Chemical component parts of calcite deposit

\begin{tabular}{|l|l|l|l|}
\hline & Oxygen (\%) & Carbon (\%) & Calcium (\%) \\
\hline Background & $\mathbf{5 8 . 0}$ & $\mathbf{1 7 . 5}$ & $\mathbf{2 4 . 5}$ \\
\hline Foreground & $\mathbf{6 0 . 6}$ & $\mathbf{1 3 . 4}$ & $\mathbf{2 6 . 0}$ \\
\hline
\end{tabular}

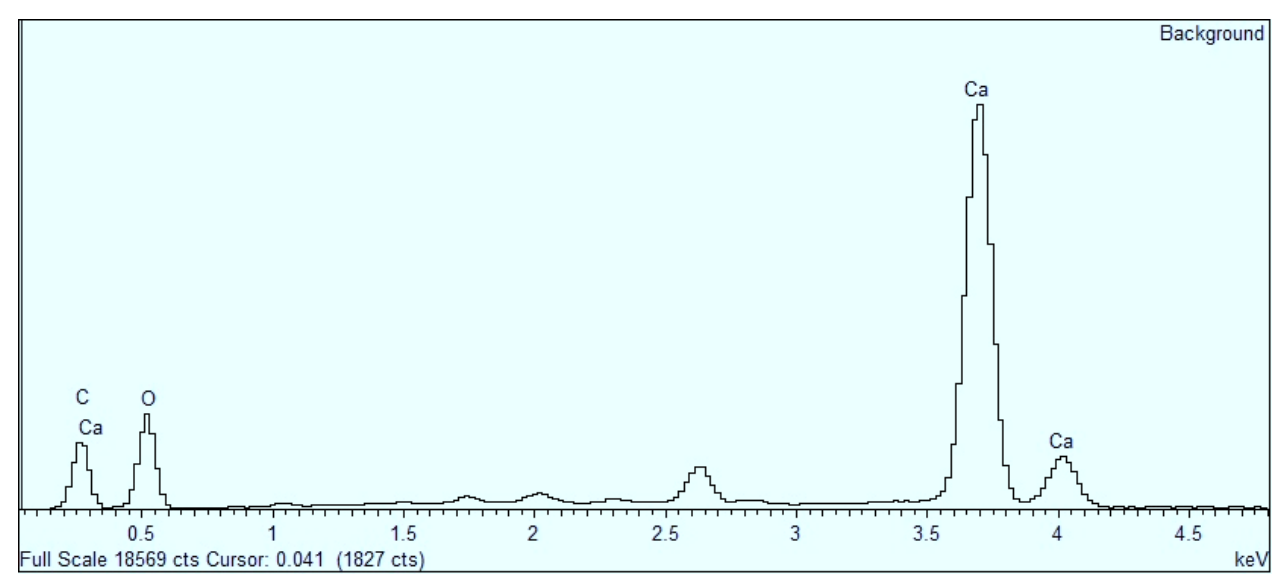

Figure 2. Energy Dispersive Spectroscopy (EDS) image

The Energy Dispersive Spectroscopy (EDS) results were tested alongside a MOH's hardness test and hydrochloric acid test which showed the calcite formation was within normal hardness associated with the formation of calcite and the acid test showed the material to be of an alkaline nature.

Following the treatment, an average oven dry weight increase of $3.6 \mathrm{~g}$ was recorded. The WCR ratio of the cubes did not effect the average weight gain for the resepctive samples.

\section{Crack sealing}

The effectiveness of the MICP crack healing properties are displayed in Figures 3 and 4.

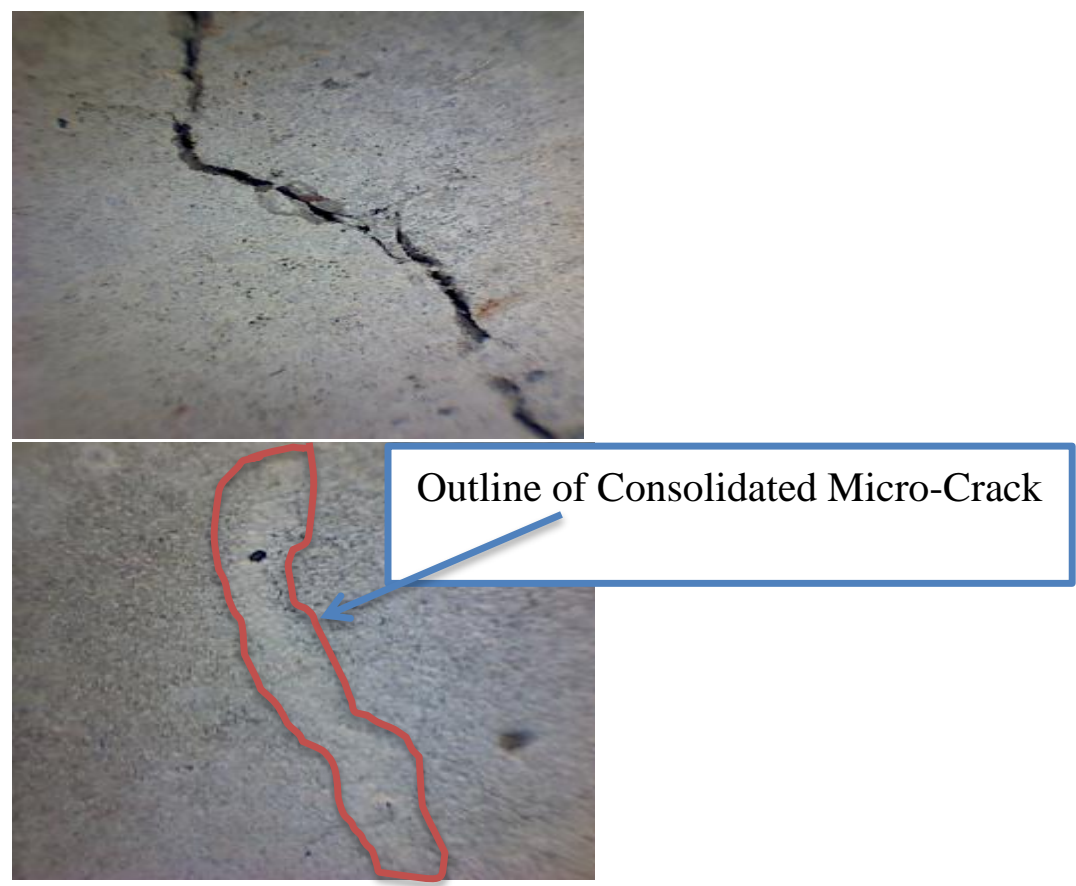

Figure 3. Above cracked fibre beam and below MICP sealing the crack 

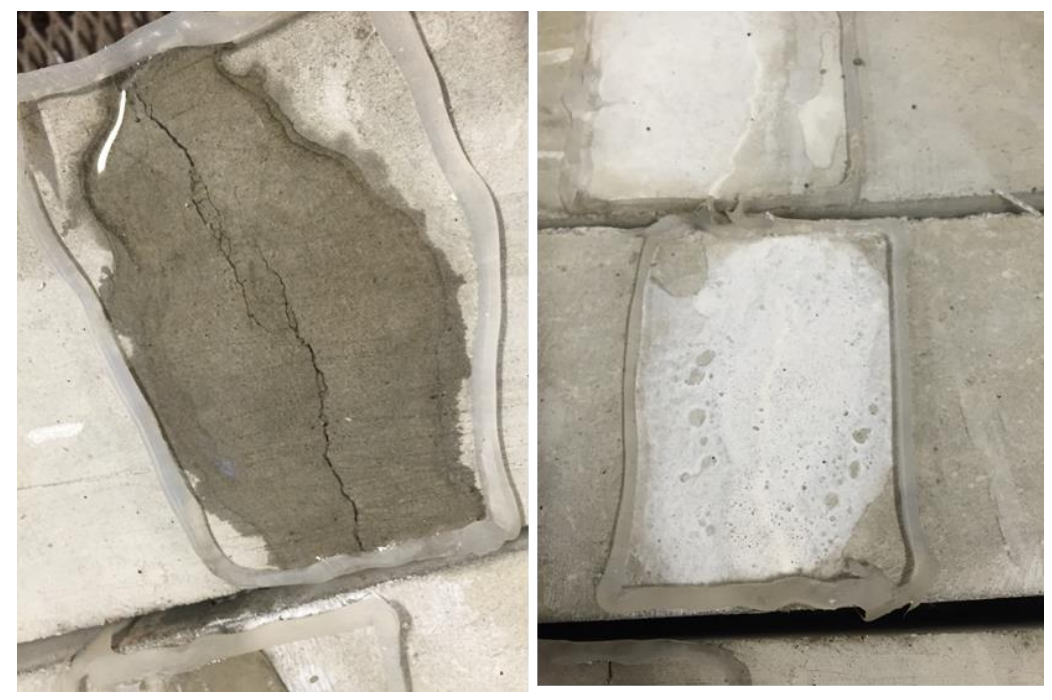

\section{Figure 4. Cracked concrete beam on left and healed concrete beams to the right.}

This study has demonstrated the potential $S$. pasteurii and consequently MICP holds in improving the integrity of finish to concrete, without the use of chemical based sealants.

\section{Surface application}

The following figures depict the results obtained from the Alicona 4G Infinite Focus scans.

\section{Mean Surface Height Deviation}

Figures 5 and 6 display how the surface height of each of the sample cubes has been altered following the MICP surface treatment. In each of the three sample cubes the mean surface height deviation has visibly reduced as the $\mathrm{CaCO}_{3}$ increased the lowest depth references. The 'Height' legend shows less surface abnormality following application.
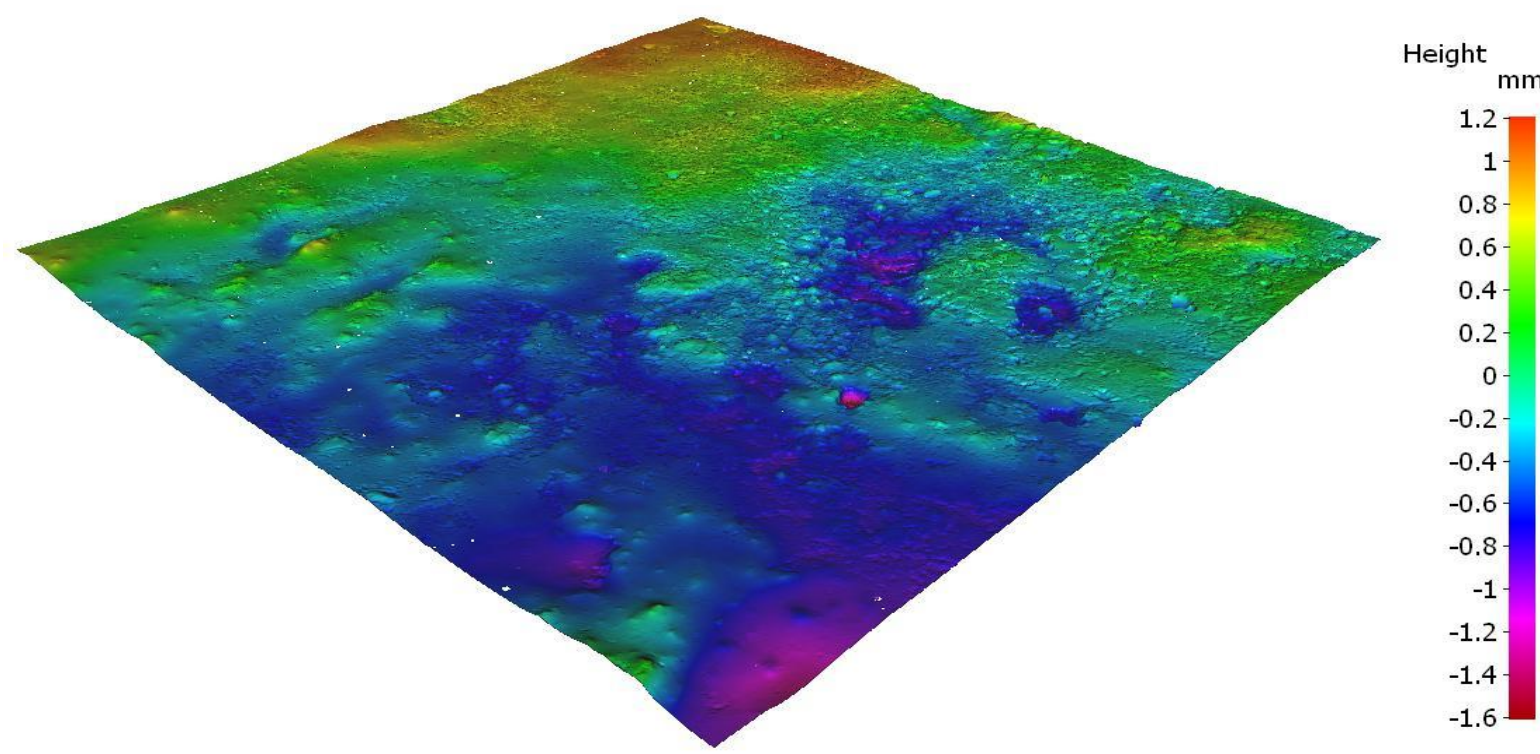

Figure 5. Cube 1: Height Deviation Scan Prior to Treatment 

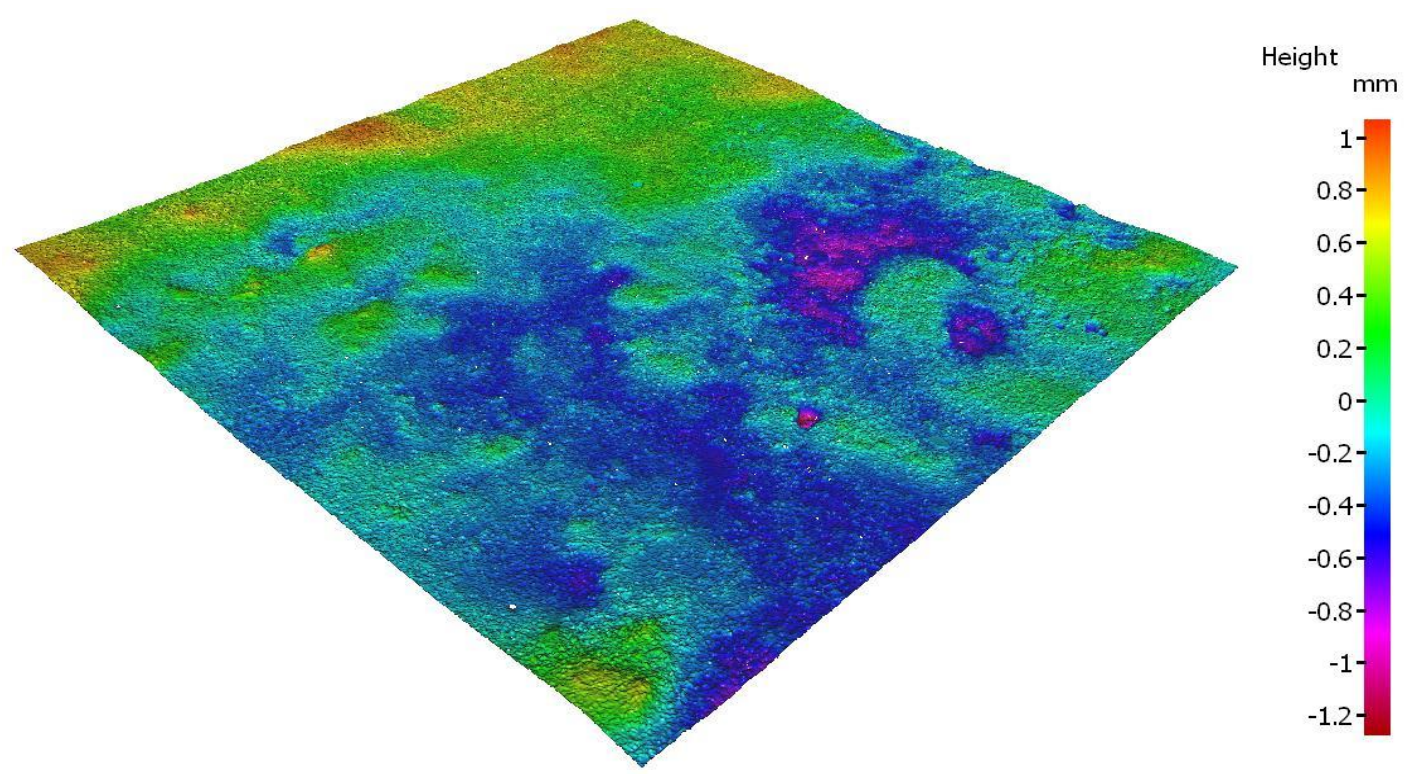

Figure 6. Cube 1: Height Deviation Scan Post Treatment

A bonding of the uneven and loose surface was observed after a surface application of bacterial broth.

\section{CONCLUSION}

By reaching an average $\mathrm{OD}_{600}$ of 2.1 over the three applications, adequate nucleation sites were provided for MICP to occur. The investigation has hereby acted as a 'proof of concept' in that MICP can perform as an organic repair alternative for concrete structures, especially in a time where heavy emphasis is placed on environmentally sustainable building solutions. The layering effect provided visible results on both the cubes and beams which had bonded with the concrete cube surface.

Although the MICP did not penetrate the cube surfaces, the bacteria successfully filled the majority of imperfections and voids on the samples.

Uneven concrete surfaces can also be smoothed using this treatment; the Alicona scanner showed a reduction in differential surface topography. This has scope to aesthetically improve concrete surfaces although the colour of calcite (white) may not be deemed aesthetically pleasing and therefore require suitable pigmentation additives.

The results, with regard to depth of calcite penetration, demonstrated the near $100 \%$ consolidation of the micro cracks to a depth of approximately $20 \mathrm{~mm}$. The use of the treatment in such a way could be plausible on a commercial scale as the cracks house the NBU, in turn pooling the solution and leading to MICP. This reduces the reliance on surface pooling which was needed with the cube samples.

The cube surface scans gave a thorough analysis of the calcite formations build up. The comparable scans showed a surface mass increase and a reduction in surface structure deviation, effectively fusing the cubes' surface with the $\mathrm{CaCO}_{3}$. With lessened surface porosity, in theory, the rate of deterioration would slow in a real world application. However, this is reliant on further porosity testing.

\section{REFERENCES}

Achal, V. and Pan, X. (2011) "Characterization of urease and carbonic anhydrase producing bacteria and their role in calcite precipitation." Current microbiology, 62(3) pp. 894-902. 
Bang, S. S., Galinat, J. K. and Ramakrishnan, V. (2001) "Calcite precipitation induced by polyurethaneimmobilized Bacillus pasteurii.” Enzyme and Microbial Technology, 28(4-5) pp. 404-409

Basheer, P. A. M. and Barbhuiya, S. A. (2010) "Pore Structure and Permeability," "Concrete Durability, A practical guide to the design of durable concrete structures", Editor Soutsos M, Thomas Telford, UK.

BRE (2000) "Corrosion of steel in concrete - durability of reinforced concrete structures," Digest 444(Part 1) pp. 2-9.

Chahal, N., Siddique, R. and Rajor, A. (2012) "Influence of bacteria on the compressive strength, water absorption and rapid chloride permeability of concrete incorporating silica fume." Construction and Building Materials. Elsevier Ltd, 37, December, pp. 645-651

De Muynck, W., De Belie, N. and Verstraete, W. (2010) "Microbial carbonate precipitation in construction materials." Ecological Engineering, 36(2) pp. 118-136.

De Muynck, W., Debrouwer, D., De Belie, N. and Verstraete, W. (2008) "Bacterial carbonate precipitation improves the durability of cementitious materials." Cement and Concrete Research, 38(7) pp. 1005-1014.

Fortin, D., Davis, B. S. and Beveridge, T. J. (1996) "Mineralization of bacterial surfaces," Chemical Geology 132.

Lambert, P. (2002) "Reinforced concrete - history, properties and durability," Corrosion Prevention Assosciation.

Richardson A E, Coventry KA, Forster A, Jamison C , (2014) "Surface consolidation of natural stone materials using microbial induced calcite precipitation", Structural Survey, Vol. 32 Iss: 3, pp 265 278

Rouchier, S., Woloszyn, M., Foray, G. and Roux, J.-J. (2013) "Influence of concrete fracture on the rain infiltration and thermal performance of building facades." International Journal of Heat and Mass Transfer. Elsevier Ltd, 61, June, pp. 340-352.

Sarda, D., Choonia, H. S., Sarode, D. D. and Lele, S. S. (2009) "Biocalcification by Bacillus pasteurii urease: a novel application." Journal of industrial microbiology \& biotechnology, 36(8) pp. 1111-5.

Siddique, R. and Chahal, N. K. (2011) "Effect of ureolytic bacteria on concrete properties." Construction and Building Materials, 25(10) Elsevier Ltd, pp. 3791-3801.

Sierra-Beltran, M. G., Jonkers, H. M. and Schlangen, E. (2014) "Characterization of sustainable bio-based mortar for concrete repair." Construction and Building Materials, 67, Elsevier Ltd, pp. 344-352.

Srinivasan, R. S., Ingwersen, W., Trucco, C., Ries, R. and Campbell, D. (2014) "Comparison of energybased indicators used in life cycle assessment tools for buildings." Building and Environment. Elsevier Ltd, 79, September, pp. 138-151. 
Stuckrath, C., Serpell, R., Valenzuela, L. M. and Lopez, M. (2014) "Quantification of chemical and biological calcium carbonate precipitation: Performance of self-healing in reinforced mortar containing chemical admixtures." Cement and Concrete Composites. Elsevier Ltd, 50 pp. 10-15.

Stocks-fischer, S., Galinat, J. K. and Bang, S. S. (1999) "Microbiological precipitation of $\mathrm{CaCO}_{3}$ ” Soil Boilogy and Biochemistry, pp. 31.

The Concrete Society (2009) "Repair of Concrete Structures with Reference to BS EN 1504."

Van Tittelboom, K., De Belie, N., De Muynck, W. and Verstraete, W. (2010) "Use of bacteria to repair cracks in concrete." Cement and Concrete Research, 40(1), Elsevier Ltd, pp. 157-166.

Wiktor, V. and Jonkers, H. M. (2011) "Quantification of crack-healing in novel bacteria-based selfhealing concrete." Cement and Concrete Composites, 33(7), Elsevier Ltd, pp. 763-770.

Wang, J. Y., Soens, H., Verstraete, W. and De Belie, N. (2014) "Self-healing concrete by use of microencapsulated bacterial spores." Cement and Concrete Research, 56, Elsevier Ltd, pp. 139-152.

Zamarreño, D. V, Inkpen, R. and May, E. (2009) "Carbonate crystals precipitated by freshwater bacteria and their use as a limestone consolidant." Applied and environmental microbiology,75(18), pp. 598190 